\title{
Preferensi Arthropoda terhadap Warna Perangkap pada Pertanaman Kopi Arabika di Desa Atang Jungket Kabupaten Aceh Tengah
}

\author{
(Preference of Arthropod to Color of Trap on Arabica Coffee Plantation in Atang Jungket \\ Village Aceh Tengah District)
}

\author{
Ulyani $^{1}$, Alfian Rusdy ${ }^{2}$, Hasnah $^{2} *$ \\ ${ }^{1}$ Mahasiswa Program Studi Agroteknologi Bidang Minat Perlindungan Tanaman, Fakultas \\ Pertanian, Universitas Syiah Kuala, Banda Aceh, 23111. \\ ${ }^{2}$ Program Studi Proteksi Tanaman, Fakultas Pertanian, Universitas Syiah Kuala, Jl. Tgk \\ Hasan Krueng Kalee No. 3, Banda Aceh, 23111 \\ *corresponding author: hasnah@unsyiah.ac.id
}

\begin{abstract}
Abstrak. Arthropoda merupakan filum yang paling dominan di antara filum hewan lainnya jika ditinjau dari keanekaragaman, penyebaran, dan jumlah spesiesnya. Pada pertanaman kopi arabika terdapat arthropoda yang berperan sebagai herbivor, musuh alami, serangga penyerbuk, serangga netral, dan dekomposer. Secara umum, tindakan pengelolaan yang dilakukan oleh petani pada pertanaman kopi di Desa Atang Jungket Kabupaten Aceh Tengah adalah dengan menggunakan pestisida sintetik tanpa mempedulikan kondisi agroekosistemnya. Supaya agroekosistem kopi tetap stabil dan berkelanjutan, maka perlu dilakukan tindakan pengelolaan yang ramah lingkungan yaitu dengan menggunakan perangkap warna dimana proses penemuan inang serangga didasari oleh faktor visual yang bertujuan untuk mengetahui warna perangkap yang disukai oleh arthropoda pada areal pertanaman kopi arabika. Pada penelitian ini digunakan metode purposive sampling (ditetapkan) dengan luas lahan $5.000 \mathrm{~m}^{2}$ yang berjumlah 138 tanaman, kemudian dibagi menjadi empat petak secara berjajar. Setiap petak diambil 20 tanaman sampel dengan menggunakan perangkap warna merah, kuning, hijau, dan putih. Peubah yang diamati meliputi komposisi dan kelimpahan arthropoda berdasarkan warna perangkap, indeks similaritas famili antar warna perangkap, serta kepadatan relatif Famili Scolytidae. Hasil penelitian menunjukkan bahwa arthropoda yang ditemukan berjumlah 2.062 individu yang terdiri dari 2 kelas, 12 ordo, dan 72 famili. Ordo Hymenoptera merupakan ordo dengan jumlah individu paling banyak. Perangkap warna kuning merupakan paling banyak memerangkap arthropoda yaitu 552 individu dibandingkan perangkap warna merah, hijau, dan putih yang masing-masingnya hanya 547 individu, 527 individu, dan 436 individu. Nilai indeks similaritas famili arthropoda antar warna perangkap tergolong rendah berarti keragaman famili yang menyusun komunitas tersebut tinggi. Kepadatan Famili Scolytidae berjumlah 0,02 individu $/ \mathrm{m}^{2}$ dan kepadatan relatif $0,04 \%$. Hal ini menunjukkan bahwa pengelolaan tanah dan tanamannya secara ekologis masih menguntungkan, tidak mengancam keberlangsungan budi daya tanaman.
\end{abstract}

Kata kunci: Keanekaragaman hayati, perangkap warna, tanaman kopi

Abstract. Arthropods are the most dominant phylum among other animal phyla when viewed from the diversity, distribution, and number of species. In arabica coffee plantation there arthropods that act as herbivor, natural enemies, pollinating insects, neutral insects, and decomposers. In general, the management actions carried out by farmers on coffee plantations in Atang Jungket Village, Central Aceh District is to use synthetic pesticides regardless of agro-ecosystem condition. For coffee agro-ecosystem to remain stable and sustainable, it is necessary to do an environmentally friendly management action that is by using color trap where the process of invention of insect host is based on visual factor which aim to know color of trap were liked by arthropod in arabica coffee plantation area. This research uses purposive sampling method with 5,000 $\mathrm{m}^{2}$ land area of 138 plants, then divided into four plots in a row. Each plot was taken 20 sample plants using red, yellow, green, and white traps. The observed variables include the composition and abundance of arthropods based on the trap color, the family similarity index between the trap colors, and the relative density of the Scolytidae Family. The results showed that the arthropods were 2,062 individuals consisting of 2 classes, 12 orders, and 72 families. The Hymenoptera Order is the order of the largest number of individuals. The yellow trap is the most arthropod trap of 552 individuals compared to the red, green, and white traps of 547 individuals, 527 individuals and 436 individuals each. The value of the arthropod family similarity index between the trap colors is low, meaning that the diversity of families that make up the community is high. The Scolytidae Family density was 
0.02 individuals $/ \mathrm{m}^{2}$ and the relative density was $0.04 \%$. This indicates that the management of land and plants are ecologically still profitable, not threatening the sustainability of cultivation of crops.

Keywords: Biodiversity, color trap, coffee plant

\section{PENDAHULUAN}

Agroekosistem pertanaman kopi merupakan suatu ekosistem binaan manusia yang proses pembentukan, peruntukan, dan perkembangannya diarahkan dalam memenuhi kebutuhan manusia, sehingga campur tangan dan tindakan manusia menjadi unsur sangat dominan (Hidayat, 2001). Banyak ekosistem perkebunan dimanipulasi untuk memperoleh produk tinggi dari tanaman yang dibudidayakan (MacKinnon et al., 2000). Pada agroekosistem perkebunan kopi tersebut ada yang berperan sebagai produsen, konsumen ataupun dekomposer. Pada suatu ekosistem terjadi proses makan dimakan yang selanjutnya akan membentuk rantai dan jaring-jaring makanan, kemudian serangga herbivor akan menjadi mangsa bagi kelompok serangga lain yang biasa disebut sebagai predator dan parasitoid (Brotowidjoyo, 1990).

Keanekaragaman jenis di suatu lahan dikatakan tinggi apabila suatu komunitas disusun oleh banyak spesies, dimana kelimpahan spesies tersebut sama atau hampir sama. Begitu pula sebaliknya, apabila suatu lahan hanya sedikit spesies yang ada serta hanya sedikit saja spesies yang dominan, maka keanekaragaman jenis pun pada lahan tersebut dikatakan rendah (Soegianto, 1994). Apabila keanekaragaman jenis tinggi, maka menunjukkan suatu komunitas memiliki kompleksitas tinggi karena dalam komunitas itu terjadi interaksi antarspesies yang tinggi. Jadi, dalam suatu komunitas yang mempunyai keanekaragaman jenis yang tinggi akan terjadi interaksi spesies yang melibatkan transfer energi (jaring makanan), predasi, kompetisi, dan pembagian relung yang secara teoritis sangat kompleks (Heddy et al., 1994).

Hasil penelitian Yusnita (2017), jumlah arthropoda yang ditemukan di perkebunan kopi pada 12 kali pengamatan sebanyak 20.117 individu yang terdiri dari 6 kelas di antaranya yaitu Arachnida, Chilopoda, Collembola, Diplopoda, Insekta, dan Malacostraca. Predator yang umum ditemukan di antaranya Famili Araneidae, Linyphidae, Oxyopidae, Tetragnathidae, Thomisidae, Dolichopodidae, Reduvidae, Formicidae, Gryllidae, dan Staphylinidae. Keberadaan serangga predator di lahan perkebunan kopi sangat ditentukan oleh beberapa faktor antara lain sumber pakan, suhu, dan kelembaban. Kesemua faktor ini sangat memengaruhi jenis serangga predator yang ada di perkebunan kopi.

Penggunaan pestisida sintetis yang tidak terkontrol seperti herbisida dapat menyebabkan kerusakan lingkungan dan timbulnya resistensi hama. Pada spektrum luas akan mematikan musuh alami dan organisme lain yang bukan sasaran pada ekosistem tersebut (Davis et al., 1998). Keanekaragaman spesies sangatlah penting pada suatu ekosistem karena hal tersebut menunjukkan bahwa ekosistem tersebut masih bagus dan alami. Keanekaragaman memiliki peran yang penting pada ekosistem dan berpengaruh pada pertanian, kesehatan pada manusia, sumber daya alam, dan perkembangan ilmu lainnya (Ewusie, 1990).

Serangga memiliki sifat khusus atau perilaku yang berbeda-beda. Perilaku tersebut dapat dipengaruhi oleh rangsangan warna maupun cahaya di sekitarnya. Pengaruh warna yang berbeda-beda pada lingkungan hidupnya akan mengubah perilaku baik serangga hama maupun musuh alami dalam memilih tempat untuk peletakan telur, mendapatkan makanan, dan mencari tempat untuk berlindung. Maka dari itu, banyak parasitoid dan predator yang juga ikut tertarik kepada warna-warna dari tumbuhan dan pantulan cahaya, hal ini diduga ada hubungan dengan tempat tinggal mangsanya (Mahrub, 1986 dalam Widyastuti, 2009). 
Respon serangga terhadap cahaya pada hakikatnya dipengaruhi oleh berbagai macam faktor termasuk intensitas cahaya dan panjang gelombang, kombinasi antara panjang gelombang, waktu pencahayaan, arah sumber cahaya dan kontras intensitas sumber cahaya dan warna untuk cahaya pada lingkungan. Dampak cahaya terhadap tingkah laku serangga bersifat kualitatif dan kuantitatif tergantung pada sumber cahaya (light bulb atau lightemitting diode [LED]) dan material (light-reflecting plate) (Honda, 2011; Johansen et al., 2011). Aproksimasi jangkauan panjang gelombang warna merah yaitu 630-760 nm, warna

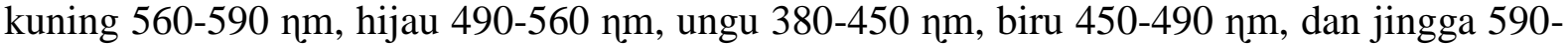
630 nm (Sugito et al., 2005).

Agroekosistem kopi berkelanjutan (sustainable coffee) menjadi isu penting perdagangan kopi dunia dengan sertifikasi sebagai salah satu instrumennya. Mengingat pentingnya hal tersebut, maka perlu diteliti preferensi arthropoda terhadap warna perangkap pada lahan pertanaman kopi arabika di Desa Atang Jungket Kabupaten Aceh Tengah. Informasi penggunaan warna perangkap pada pertanaman kopi dapat dijadikan sebagai alternatif pengendalian guna tercapainya kelestarian ekosistem tersebut. Penelitian ini bertujuan untuk mengetahui warna perangkap yang disukai oleh arthropoda pada pertanaman kopi arabika di Desa Atang Jungket Kabupaten Aceh Tengah.

\section{METODE PENELITIAN}

\section{Tempat dan Waktu Penelitian}

Penelitian ini dilaksanakan pada pertanaman kopi rakyat jenis arabika di Desa Atang Jungket Kecamatan Bies Kabupaten Aceh Tengah dan di Laboratorium Hama Tumbuhan Program Studi Proteksi Tanaman Fakultas Pertanian Universitas Syiah Kuala mulai Bulan Mei sampai dengan November 2017.

\section{Alat dan Bahan Penelitian}

Alat yang digunakan pada penelitian ini adalah GPS (Global Positioning System), meteran, gunting, kuas, thermometer, hygrometer, pentul, gelas ukur, botol film, mikroskop binokuler, pinset, penggaris, kamera, dan buku identifikasi. Bahan yang digunakan pada penelitian ini adalah botol bekas air mineral volume $600 \mathrm{ml}$, kantong plastik transparan, metanol $100 \%$, air sabun, tali rafia, cat minyak, plastik bening, lem perekat, alat tulis, kertas label, dan alkohol $70 \%$.

\section{Penentuan Lokasi Pengambilan Sampel}

Lokasi pengambilan sampel dilaksanakan pada pertanaman kopi rakyat jenis arabika di Desa Atang Jungket Kecamatan Bies Kabupaten Aceh Tengah dengan ketinggian 1.400 m dpl. Tanaman kopi yang dijadikan sebagai sampel merupakan tanaman kopi arabika varietas Gayo I yang berumur 20 tahun. Pertanaman kopi ini dikelola secara konvensional dengan luas areal 0,5 ha. Pengambilan sampel dilakukan dengan menggunakan metode purposive sampling (ditetapkan) berdasarkan populasi tanaman minimal 10\% (Gomez \& Gomez, 1995). Luas lahan pertanaman kopi dibagi menjadi empat bagian secara berjajar, sehingga setiap petak luasnya adalah $1.250 \mathrm{~m}^{2}$ dengan jumlah tanaman 138 tanaman. Setiap petak diambil 20 tanaman sampel, sehingga didapatkan 80 tanaman sampel. Pada petak 1, warna perangkap merah; petak 2, warna perangkap kuning; petak 3, warna perangkap hijau; dan petak 4, warna perangkap putih. 


\section{Pengumpulan Sampel}

Semua arthropoda yang terperangkap dimasukkan ke dalam botol film berisi alkohol 70\% agar awet untuk memudahkan dalam proses identifikasi yang dilakukan di Laboratorium Hama Tumbuhan Program Studi Proteksi Tanaman Fakultas Pertanian Universitas Syiah Kuala.

\section{Peubah yang Diamati}

\section{Komposisi dan Kelimpahan Arthropoda berdasarkan Warna Perangkap}

Jumlah individu dari semua arthropoda yang terperangkap dihitung dan dipisahkan berdasarkan warna perangkap.

\section{Indeks Similaritas Famili antar Warna Perangkap}

Indeks similaritas famili dihitung menggunakan rumus indeks similaritas Sorensen (Barbour et al., 1987) sebagai berikut.

$$
\text { IS }=\frac{2 a}{2 a+b+c}
$$

Keterangan:

IS = Indeks similaritas Sorensen

$\mathrm{a}=$ Jumlah famili yang sama terdapat pada perangkap warna $\mathrm{a}$ dan $\mathrm{b}$

$\mathrm{b}=$ Jumlah famili yang terdapat pada perangkap warna $\mathrm{a}$

$\mathrm{c}=$ Jumlah famili yang terdapat pada perangkap warna $\mathrm{b}$

Penentuan indeks similaritas Sorensen didasari oleh kehadiran dan ketidakhadiran suatu famili pada suatu perangkap warna. Kriteria yang digunakan untuk menginterpretasikan similaritas Sorensen menurut Barbour et al. (1987) yaitu dapat dilihat pada Tabel 1.

Tabel 1. Kriteria Indeks Similaritas Sorensen

\begin{tabular}{ll}
\hline Nilai Tolok Ukur & Kriteria \\
\hline IS $<0,25$ & Sangat rendah \\
IS $>0,25-0,50$ & Rendah \\
IS $>0,50-0,75$ & Tinggi \\
IS $>0,75$ & Sangat tinggi \\
\hline
\end{tabular}

\section{Kepadatan Relatif Famili Scolytidae}

Kepadatan relatif digunakan untuk membandingkan kepadatan suatu famili dengan semua famili yang terdapat dalam unit contoh. Kepadatan relatif dapat dihitung dengan menggunakan rumus (Suin, 2012) sebagai berikut.

$$
\text { Kepadatan Populasi Famili Scolytidae }=\frac{\text { Jumlah Individu Famili Scolytidae }}{\text { Luas Areal }}
$$

$$
\mathrm{KR}=\frac{\text { Kepadatan Populasi Famili Scolytidae }}{\text { Jumlah K Semua Famili }} \times 100 \%
$$

Keterangan:

$\begin{array}{ll}\mathrm{KR} & =\text { Kepadatan Relatif }(\%) \\ \mathrm{K} & =\text { Kepadatan (individu } / \mathrm{m}^{2} \text { ) }\end{array}$




\section{HASIL DAN PEMBAHASAN}

\section{Komposisi dan Kelimpahan Arthropoda berdasarkan Warna Perangkap}

Warna mampu memengaruhi aktivitas dan perilaku arthropoda pada suatu ekosistem. Ketertarikannya terhadap warna-warna tertentu menyebabkannya tertarik untuk mendekati warna yang ia sukai. Umumnya warna yang disukai adalah warna yang mirip dengan warna inangnya. Selain itu, arthropoda umumnya mendekati warna karena akan meletakkan telur dan berlindung dari organisme yang akan memangsanya.

Berdasarkan hasil penelitian yang telah dilakukan pada pertanaman kopi arabika di Desa Atang Jungket Kecamatan Bies Kabupaten Aceh Tengah, jumlah arthropoda yang terperangkap dengan menggunakan perangkap warna yaitu sebanyak 2.062 individu yang terdiri dari 2 kelas, 12 ordo, dan 72 famili. Ordo Hymenoptera merupakan ordo dengan jumlah individu yang paling banyak terperangkap dibandingkan dengan Ordo Diptera, Araneae, Coleoptera, Homoptera, Orthoptera, Blattodea, Hemiptera, Lepidoptera, Mantodea, Mecoptera, dan Psocoptera, untuk lebih jelas berikut ini disajikan data hasil pengamatan kelimpahan arthropoda pada setiap perangkap warna.

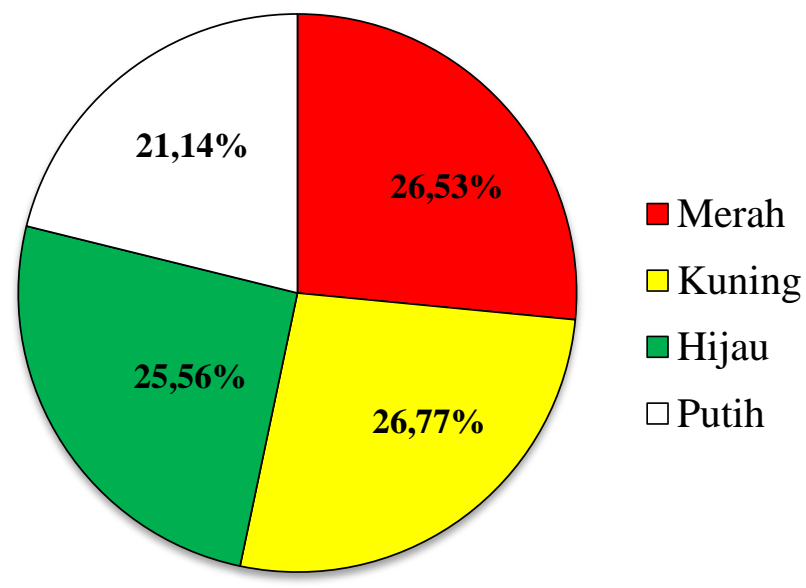

Gambar 1. Kelimpahan Arthropoda berdasarkan Warna Perangkap

Pada Gambar 1 dapat dilihat bahwa jumlah arthropoda yang terperangkap pada perangkap warna kuning lebih banyak yaitu $26,77 \%$, kemudian diikuti perangkap warna merah, hijau, dan paling sedikit terdapat pada perangkap warna putih yaitu $21,14 \%$. Hal ini membuktikan bahwa warna perangkap juga berpengaruh terhadap perilaku arthropoda. Umumnya serangga lebih tertarik pada warna kuning, sehingga populasinya lebih tinggi pada perangkap kuning. Sesuai dengan hasil penelitian Shimoda \& Honda (2013) bahwa serangga yang tertarik pada warna kuning di antaranya adalah wereng, kutu daun, thrips, dan penggorok daun. Selanjutnya Amir \& Budi (2012) menambahkan bahwa serangga thrips pada tanaman rosela minuman sangat respon terhadap perangkap berwarna kuning karena persentase refleksi cahaya (intensitas) warna kuning lebih tinggi dibandingkan warna biru dan putih, kemudian diikuti oleh perangkap warna biru dan paling sedikit populasinya pada perangkap warna putih. Selain thrips, juga terdapat arthropoda lain yaitu Ordo Diptera, Hemiptera, dan Araneae.

Sugito et al. (2005) menyatakan bahwa secara fisika panjang gelombang warna paling rendah adalah warna ungu (380-450 Пm), kemudian diikuti oleh warna biru (450-490 $\eta \mathrm{m})$, warna hijau (490-560 nm), warna kuning (560-590 nm), warna jingga (590-630 пm), dan paling tinggi merupakan warna merah (630-760 nm). Selanjutnya Sodiq (2009) menyatakan 
bahwa serangga umumnya panjang gelombang yang hanya mampu memberikan respon terhadap cahaya adalah 300-400 nm sampai dengan 600-650 nm.

Arthropoda yang dominan terperangkap adalah Ordo Hymenoptera dan Ordo Diptera. Famili dari Ordo Hymenoptera yang terperangkap paling dominan adalah Famili Ichneumonidae dan Formicidae, kemudian diikuti oleh Famili Apidae, Eulophidae, Braconidae, Diapriidae, Colletidae, Bethylidae, Platygastridae, Tiphiidae, Megaspilidae, Aphelinidae dan yang paling sedikit adalah Apoidea dan Tenthredinidae. Serangga dari Ordo Hymenoptera umumnya bersifat sebagai musuh alami (parasitoid dan predator) dan sangat berperan dalam menjaga keseimbangan alam dari agroekosistem. Banyaknya jumlah serangga Ordo Hymenoptera yang terperangkap membuktikan bahwa serangga ordo tersebut tersebar luas di pertanaman kopi rakyat jenis arabika di Desa Atang Jungket Kabupaten Aceh Tengah. Famili Formicidae yang dominan adalah Crematogaster sp. yang merupakan predator dari serangga hama di pertanaman kopi. Sesuai dengan hasil penelitian Yusnita (2017) bahwa serangga Famili Formicidae mencapai 14.562 individu pada perkebunan kopi rakyat di Desa Karang Tengah Kabupaten Bogor. Selanjutnya Hamdi et al. (2015) menambahkan bahwa jumlah parasitoid dari Famili Ichneumonidae pada lahan kopi yang dikelola secara non organik di Kecamatan Atu Lintang Kabupaten Aceh Tengah sebanyak 143 individu, sedangkan pada lahan kopi yang dikelola secara organik sebanyak 13.689 individu.

Banyaknya serangga dari Ordo Hymenoptera khususnya Famili Ichneumonidae di lokasi penelitian ini ada kaitannya dengan sistem pengelolaan budi daya tanaman kopi di areal tersebut yaitu kurangnya input teknologi seperti pemupukan dan penggunaan pestisida akibatnya keseimbangan musuh alami dan hama masih terjaga. Sebagaimana hasil penelitian Hamdi et al. (2015) bahwa serangga Famili Ichneumonidae jumlah individunya lebih banyak dibandingkan dengan famili yang lain baik pada lahan kopi organik maupun non organik.

Tingginya populasi Famili Formicidae terutama semut predator spesies Crematogaster sp. dan Dolichoderus sp. yang terperangkap. Hal ini ada kaitannya dengan lokasi pemasangan perangkap dengan habitat hidup (sarang) dari serangga tersebut yaitu berada pada bagian-bagian tanaman kopi baik pada cabang maupun pada buah. Sebagaimana pernyataan Surya \& Rubiah (2016) bahwa semut hitam (Famili: Formicidae) membuat sarangnya di atas permukaan tanah dan tempat-tempat kering serta gelap yang tidak jauh dari sumber makanannya. Semut ini biasanya akan keluar dari sarangnya untuk menjalankan aktivitas ketika pagi dan sore hari di saat suhu udara tidak terlalu panas. Selain itu, adanya embun-embun madu yang terdapat pada daun tanaman kopi diduga juga menjadi penyebab semut tertarik untuk mendekat. Sebagaimana pernyataan Yusdira et al. (2014) bahwa semut suka mencari cadangan gula misalnya seperti embun madu yang dibutuhkannya untuk energi tambahan pada saat memasuki periode awal dalam pembuatan sarang.

Serangga dari Ordo Diptera yang paling banyak terperangkap adalah Famili Muscidae, kemudian diikuti Famili Sciaridae, Tephritidae, sedangkan famili lainnya hanya sedikit individu yang terperangkap. Banyaknya serangga Ordo Diptera yang terperangkap ada kaitannya dengan habitat hidupnya yaitu pada kondisi kelembaban tanah tinggi serta banyaknya sampah-sampah organik yang terdapat pada lahan penelitian.

Banyaknya populasi serangga Ordo Diptera dari Famili Tephritidae yang terperangkap diduga karena adanya ketersediaan buah-buahan sebagai inangnya seperti buah nangka dan alpukat yang dijadikan sebagai tanaman sela di lokasi penelitian. Pada saat penelitian dilaksanakan, tanaman tersebut dalam kondisi berbuah, sehingga diduga menjadi penyebab banyaknya lalat buah dari Famili Tephritidae yang terperangkap. Tephritidae tersebut bukanlah hama pada tanaman kopi. Namun, diduga penyebab ketertarikannya terhadap warna perangkap yang dipasang pada cabang tanaman kopi. Sesuai dengan hasil 
penelitian Syofia et al. (2012) bahwa lalat buah dari Famili Tephritidae pada tanaman belimbing yang terperangkap paling banyak pada perangkap warna kuning, selanjutnya diikuti oleh warna biru, hijau, merah, dan hitam.

Pada penelitian ini, jumlah individu dari Ordo Araneae yang terperangkap adalah 195 individu dari 13 famili. Famili dari Ordo Araneae paling dominan yang terperangkap adalah Famili Salticidae, kemudian diikuti oleh Famili Zodariidae, Scytodidae, Clubionidae, Eutichuridae, Lycosidae, Linyphiidae, Theridiidae, Miturgidae, Theridiosomatidae, Thomisidae dan paling sedikit pada Famili Araneidae dan Philodromidae masing-masing berjumlah 2 individu. Ordo Araneae umumnya berperan sebagai predator. Kehadiran labalaba ini membuktikan bahwa kondisi agroekosistem tanaman kopi masih stabil dan kehadiran serangga hama masih berada pada posisi keseimbangan umum. Menurut Suana (2005) bahwa habitat laba-laba sangat berlimpah dan beranekaragam. Laba-laba akan berpindah dari satu habitat ke habitat yang lain apabila tempat yang mereka tinggalkan sebelumnya sudah tidak layak huni. Suana \& Haryanto (2013) menambahkan bahwa tingginya kelimpahan laba-laba pada suatu perkebunan belum tentu berpotensi sebagai musuh alami untuk hama. Masingmasing dari spesies laba-laba mempunyai waktu aktif dan mangsa yang berbeda. Beragamnya spesies laba-laba, maka potensinya dalam mengendalikan beragam hama juga semakin besar.

Serangga Famili Psyllidae yang terperangkap salah satunya adalah kutu loncat (Heteropsylla cubana) yang merupakan hama pada tanaman lamtoro. Tanaman tersebut merupakan tanaman penaung pada areal pertanaman kopi. Sesuai dengan pernyataan Panjaitan et al. (2012) bahwa hama utama dari tanaman lamtoro adalah kutu loncat yang biasanya menyerang bagian tangkai, kuncup daun, tunas, dan daun muda yang dapat menghambat pertumbuhan lamtoro. Selanjutnya Nuraeni (2015) menambahkan bahwa hama kutu loncat tersebut merupakan hama utama yang cukup merusak serta dapat menyebabkan defoliasi dan pada serangan hebat dapat mengakibatkan kematian pada tanaman tersebut. Tanaman lamtoro merupakan tanaman multiguna terutama sebagai tanaman peneduh atau sebagai pakan ternak.

Persebaran arthropoda pada suatu ekosistem sangat dipengaruhi oleh kondisi iklim dan ketersediaan inang yang ada pada habitat tersebut. Sebagaimana pernyataan McPheron \& Steck (1996) bahwa populasi suatu individu dipengaruhi oleh beberapa faktor di antaranya adalah suhu, inang, dan kemampuan bereproduksi. Selanjutnya Yusnita (2017) menambahkan bahwa kehidupan serangga dianggap sukses jika ditunjang dari faktor kemampuan beradaptasi yang cepat, kemampuan beradaptasi pada lingkungan ekstrim, keanekaragaman tinggi, siklus hidup singkat, dan daya reproduksi tinggi. Haneda et al. (2013) juga menyatakan bahwa umumnya keanekaragaman dan kelimpahan serangga ditentukan oleh faktor lingkungan tertentu seperti suhu dan kelembaban udara. Suhu tersebut akan memengaruhi aktivitas serangga, penyebaran geografis dan lokal juga perkembangannya, sedangkan kelembaban dapat memengaruhi penguapan cairan tubuh serangga tersebut dan dalam pemilihan habitat yang sesuai bagi mereka.

\section{Similaritas Famili Arthropoda antar Perangkap Warna}

Nilai indeks similaritas Sorensen arthropoda antar perangkap warna tergolong rendah. Hal ini menunjukkan bahwa komposisi famili yang menyusun komunitas tersebut tingkat kesamaannya masih rendah. Secara lebih rinci, nilai indeks similaritas tersebut dapat dilihat pada Tabel 2 berikut. 
Tabel 2. Nilai Indeks Similaritas Famili Arthropoda antar Warna Perangkap

\begin{tabular}{llll}
\hline \multicolumn{2}{l}{ Warna } & Perangkap & Indeks Similaritas \\
\hline Merah & vs & Kuning & Rendah \\
Merah & vs & Hijau & Rendah \\
Merah & vs & Putih & Rendah \\
Kuning & vs & Hijau & Rendah \\
Kuning & vs & Putih & Rendah \\
Hijau & vs & Putih & Rendah \\
\hline
\end{tabular}

Sumber: Data Penelitian 2017

Pada Tabel 2 ini dapat dilihat bahwa nilai indeks similaritas antar famili arthropoda pada perangkap warna masih tergolong rendah. Rendahnya tingkat similaritas famili arthropoda antara perangkap warna diduga ada kaitan dengan tingkat keragaman arthropoda pada lahan pertanaman kopi. Sebagaimana pernyataan Setiadi (2005) bahwa semakin rendahnya tingkat similaritas pada setiap kombinasi stasiun pengamatan berarti semakin kecil nilai indeks similaritasnya. Hal ini terjadi karena adanya variasi kondisi lingkungan baik fisik, kimia maupun interaksi antara spesies pada sepanjang gradien wilayah yang diteliti, sehingga spesies yang hidup pun menjadi bervariasi.

\section{Kepadatan Relatif Famili Scolytidae}

Serangga Famili Scolytidae sebagian besar adalah serangga herbivor dengan nilai kepadatan yaitu 0,02 individu $/ \mathrm{m}^{2}$, sedangkan kepadatan relatif yang dihasilkan adalah 0,04\%. Kepadatan Famili Scolytidae ini didominansi oleh hama H. hampei yang merupakan hama utama pada pertanaman kopi. Anwar \& Ginting (2013) menyatakan bahwa jika A adalah jenis serangga yang merugikan pada kondisi pertanian, semakin tinggi nilai $\mathrm{K}$ atau KR berarti pengelolaan tanah dan tanamannya secara ekologis tidak menguntungkan dan pada suatu nilai tertentu (ambang batas) dapat mengancam keberlangsungan budi daya tanaman tersebut. Selain itu, juga dipengaruhi oleh kelimpahan suatu serangga lain yang bertindak sebagai predator bagi jenis serangga merugikan tersebut.

Ketersediaan inang yang berlimpah mampu membuat suatu serangga bertahan hidup. Namun, bila terjadi sebaliknya dimana ketersediaan inang tidak ada, maka serangga tersebut akan berpindah atau migrasi ke lokasi lain yang ada inangnya untuk kelanjutan hidupnya. Selain itu, faktor lingkungan diduga juga turut berperan dalam menentukan tingkat kepadatan suatu komunitas di agroekosistem. Faktor fisik dari lingkungan seperti suhu, kelembaban, warna, intensitas cahaya, dan angin. Hal ini merupakan faktor yang penting bagi serangga untuk melanjutkan perkembangan dan pertumbuhannya. Serangga memiliki kisaran faktor fisik tertentu bagi masing-masing untuk bertahan hidup. Sebagaimana pernyataan Natawigena (1990) bahwa kepadatan populasi suatu organisme dipengaruhi oleh dua faktor yaitu faktor internal dan faktor eksternal. Faktor internal yang dimaksud adalah kemampuan berkembang biak, perbandingan kelamin, sifat mempertahankan diri, daur hidup, dan umur imago. Faktor eksternal tersebut adalah faktor fisik seperti suhu, kelembaban udara, cahaya, warna, bau, dan angin. Selain kedua faktor tersebut juga terdapat faktor lain yaitu faktor makanan dan faktor hayati. Selanjutnya Tseniya (2016) menambahkan bahwa nilai kepadatan suatu jenis dan kepadatan relatif serangga tanah tergantung pada habitat, ketersediaan makanan, kondisi lingkungan (faktor fisika kimia tanah), dan daya reproduksi. Apabila kondisi tersebut tidak mendukung, maka kepadatan serangga tanah pun akan menurun karena terjadinya ketidakseimbangan ekosistem. 


\section{KESIMPULAN DAN SARAN}

1. Pola pertanaman kopi di Desa Atang Jungket Kabupaten Aceh Tengah masih bisa dikatakan semi organik karena keanekaragaman arthropodanya masih tinggi.

2. Secara keseluruhan, perangkap berwarna kuning lebih banyak memerangkap arthropoda dibandingkan perangkap yang lain. Hal ini membuktikan bahwa warna perangkap berpengaruh terhadap perilaku dan aktivitas arthropoda, sehingga menentukan kelimpahan arthropoda tersebut. Tingginya kelimpahan arthropoda pada suatu ekosistem akibat masih stabilnya kondisi pada agroekosistem tersebut dimana rantai makanan masih terjalin dengan baik.

3. Nilai indeks similaritas famili arthropoda antar perangkap warna tergolong rendah yang berarti ada kaitannya dengan tingkat keragaman pada lokasi penelitian dan nilai kepadatan relatif Famili Scolytidae adalah 0,04\% yang didominansi oleh hama $H$. hampei, namun tidak mengancam keberlangsungan budi daya tanaman kopi.

\section{DAFTAR PUSTAKA}

Amir, A. M. \& U. S. Budi. 2012. Preferensi perangkap berwarna terhadap thrips dan serangga lainnya pada tanaman rosela minuman (Hibiscus sabdariffa var. sabdarifa). Balai Penelitian Tanaman Pemanis dan Serat, Malang.

Anwar, E. K. \& R. C. B. Ginting. 2013. Mengenal Fauna Tanah dan Cara Identifikasinya. IAARD Press, Jakarta.

Barbour, M. G., J. K. Burk, \& W. D. Pitts. 1987. Terrestrial Plant Ecology. The Benyamin/Cummings Publishing Company. Inc., Los Angeles.

Brotowidjoyo, M. D. 1990. Zoologi Dasar. Erlangga, Jakarta.Davis, M., B. Dinham, \& S. Williamson. 1998. Growing coffee with IPM. Pesticides Action Network UK. Pest Managemet Notes. 9: 1-4.

Ewusie, J. Y. 1990. Pengantar Ekologi Tropika (terjemahan U. Tanuwidjaja). ITB, Bandung.

Gomez, K. A. \& A. A. Gomez. 1995. Prosedur Statistik untuk Penelitian Pertanian (terjemahan E. Syamsuddin \& J. S. Baharsyah). Universitas Indonesia, Jakarta.

Hamdi, S., Sapdi, \& Husni. 2015. Komposisi dan struktur komunitas parasitoid Hymenoptera antara kebun kopi yang dikelola secara organik dan konvensional di Kabupaten Aceh Tengah. J. Floratek. 10(2): 44-51.

Haneda, N. F., C. Kusmana, \& F. D. Kusuma. 2013. Keanekaragaman serangga di ekosistem mangrove. J. Silvikultur Tropika. 4(1): 42-46.

Heddy, S., Metty, \& Kurniati. 1994. Prinsip-prinsip Dasar Ekologi: Suatu Bahasan tentang Kaidah Ekologi dan Penerapannya. PT. Raja Grafindo Persada, Jakarta.

Hidayat, A. 2001. Metode Pengendalian Hama. Direktorat Pendidikan Nasional, Jakarta.

Honda, K. 2011. Reactions to light in insects and practical applications. J. Soc. Biomech. 35: 233-236.

Johansen, N. S., I. Vanninen, D. M. Pinto, A. I. Nissinen, \& L. Shipp. 2011. In the light of new greenhouse technologies: 2. Direct effects of artificial lighting on arthropods and integrated pest management in greenhouse crops. Ann. Appl. Biol. 159: 1-27. 
MacKinnon, K., G. Hatta, H. Halim, \& A. Mangalik. 2000. Ekologi Kalimantan. Prenhallindo, Jakarta.

McPheron, B. A. \& G. J. Steck. 1996. Fruit Fly Pests. St. Lucie Press, Florida.

Natawigena, H. 1990. Pengetahuan Dasar Pengendalian Hama Terpadu (Integrated Pest Control). Edisi 2. Armico, Bandung.

Nuraeni, Y. 2015. Hama utama tanaman lamtoro (Leucaena leucocephala (Lam.) de Wit) dan aspek pengendaliannya. Galam. 1(2): 13-17.

Panjaitan, T. S., Sutarta, M. Fauzan, \& Prisdiminggo. 2012. Perbanyakan lamtoro melalui persemaian. http://www.litbang.pertanian.go.id. Diakses tanggal: 12 Desember 2017.

Setiadi, D. 2005. Keanekaragaman spesies tingkat pohon di taman wisata alam ruteng, Nusa Tenggara Timur. Biodiversitas. 6(2): 118-122.

Shimoda, M. \& K. Honda. 2013. Insect reactions to light and its applications to pest management. Appl. Entomol. Zool. 48: 413-421.

Sodiq, M. 2009. Ketahanan Tanaman terhadap Hama. Universitas Pembangunan Nasional Veteran, Jawa Timur.

Soegianto, A. 1994. Ekologi Kuantitatif. Usaha Nasional, Surabaya.

Suana, I. W. 2005. Bioekologi laba-laba pada bentang alam pertanian di Cianjur: kasus daerah aliran sungai (DAS) Cianjur, sub-sub DAS Citarum Tengah, Kabupaten Cianjur, Jawa Barat. Disertasi. Institut Pertanian Bogor, Bogor.

Suana, I. W. \& H. Haryanto. 2013. Keanekaragaman laba-laba dan potensinya sebagai musuh alami hama tanaman jambu mete. J. Entomol. Indon. 10(1): 24-30.

Sugito, H., W. SB, K. S. Firdausi, \& S. Mahmudah. 2005. Pengukuran panjang gelombang sumber cahaya berdasarkan pola interferensi celah banyak. Berkala Fisika. 8(2): 3744.

Suin, N. M. 2012. Ekologi Hewan Tanah. Bumi Aksara, Jakarta.

Surya, E. \& Rubiah. 2016. Kelimpahan musuh alami (predator) pada tanaman jagung di Desa Saree Kecamatan Lembah Seulawah Kabupaten Aceh Besar. Serambi Saintia. 4(2): $10-18$

Syofia, I., Nursamsi, \& H. Indrian. 2012. Uji efektifitas beberapa warna perangkap basah untuk mengendalikan hama lalat buah (Bactrocera sp.) pada tanaman belimbing. Agrium. 17(3): 182-185.

Tseniya, F. E. 2016. Kepadatan serangga tanah di kebun kopi PTPN XII Desa Bangelan, Kecamatan Wonosari, Kabupaten Malang. Skripsi. Universitas Islam Negeri (UIN) Maulana Malik Ibrahim, Malang.

Widyastuti, U. Y. 2009. Ketertarikan Spodoptera litura F. terhadap papan perangkap berwarna di area tanaman melon (Cucumis melo L.) di Desa Bayuran Bantul. Skripsi. Universitas Atma Jaya Yogyakarta, Yogyakarta.

Yusdira, A., E. Mukhlis, \& M. Sitanggang. 2014. Budi Daya Kroto Sistem Stoples. PT. Agro Media Pustaka, Jakarta.

Yusnita, I. 2017. Kelimpahan arthropoda predator dan arthropoda lainnya pada perkebunan kopi rakyat di Desa Karang Tengah Kabupaten Bogor. Skripsi. Institut Pertanian Bogor, Bogor. 